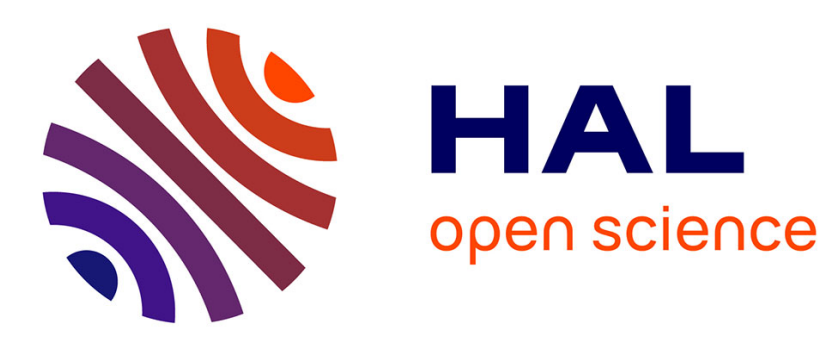

\title{
Diel shift of king penguin swim speeds in relation to light intensity changes
}

Kozue Shiomi, Katsufumi Sato, Yves Handrich, Charles-André Bost

\section{To cite this version:}

Kozue Shiomi, Katsufumi Sato, Yves Handrich, Charles-André Bost. Diel shift of king penguin swim speeds in relation to light intensity changes. Marine Ecology Progress Series, 2015, 561, pp.233-243. 10.3354/meps11930 . hal-01444616

\section{HAL Id: hal-01444616 \\ https://hal.science/hal-01444616}

Submitted on 21 Feb 2022

HAL is a multi-disciplinary open access archive for the deposit and dissemination of scientific research documents, whether they are published or not. The documents may come from teaching and research institutions in France or abroad, or from public or private research centers.
L'archive ouverte pluridisciplinaire HAL, est destinée au dépôt et à la diffusion de documents scientifiques de niveau recherche, publiés ou non, émanant des établissements d'enseignement et de recherche français ou étrangers, des laboratoires publics ou privés. 


\title{
Diel shift of king penguin swim speeds in relation to light intensity changes
}

\author{
Kozue Shiomi ${ }^{1,5, *}$, Katsufumi Sato ${ }^{1}$, Yves Handrich ${ }^{2,3}$, Charles A. Bost ${ }^{4}$ \\ ${ }^{1}$ Atmosphere and Ocean Research Institute, University of Tokyo, 5-1-5 Kashiwanoha, Kashiwa, Chiba 277-8564, Japan \\ ${ }^{2}$ Université de Strasbourg, IPHC, 23 rue Becquerel, 67087 Strasbourg, France \\ ${ }^{3}$ CNRS, UMR 7178, 23 rue Becquerel, 67087 Strasbourg, France \\ ${ }^{4}$ Centre d'Etudes Biologiques de Chizé, UMR 7372 CNRS-Université de la Rochelle, 79360 Villiers en Bois, France \\ ${ }^{5}$ Present address: National Institute of Polar Research, 10-3 Midori-cho, Tachikawa, Tokyo 190-8518, Japan
}

\begin{abstract}
It is generally expected that animals, including marine organisms, travel at speeds achieving the minimum energetic cost of transport. However, several factors cause variation in speeds within the energetically acceptable range. Light intensity is known to affect movement speeds in some flying and walking insects, which reduce speeds at low light levels. This is explained as compensation for degraded temporal resolution of vision in dim light by maintaining the rate of information gained per unit of travelling distance. Such a relationship between ambient light intensity and movement speeds is expected for any visual system in principle, but has not been examined in any marine species. As a mesopelagic forager, king penguins Aptenodytes patagonicus regularly commute between their breeding colonies and productive foraging areas over several hundreds of kilometres. During these trips, they experience a wide variation in light intensity between day and night, as well as within daylight hours, as dives often reach deeper than $100 \mathrm{~m}$. The present study investigated diel patterns in the swim speeds of king penguins in relation to light intensity experienced within dives. King penguins gradually decreased their cruising speeds around dusk and increased them again around dawn. This resulted in consistently slower speeds in nocturnal dives. Correspondingly, the underwater light levels estimated were always higher in diurnal dives, even at depths greater than $100 \mathrm{~m}$. The slower swim speeds after dusk may facilitate travelling and occasional prey detection in the dark. These results suggest that a common behavioural response to ambient light levels has evolved in different taxa of animals.
\end{abstract}

KEY WORDS: Bio-logging $\cdot$ Diel cycle $\cdot$ Diving behaviour $\cdot$ Foraging $\cdot$ Movement $\cdot$ Penguins Vision

Resale or republication not permitted without written consent of the publisher

\section{INTRODUCTION}

For animals travelling in the marine environment, speed is one of the parameters that should be optimized for energetically efficient movements. However, there are likely to be some factors causing variation of speeds within the energetically acceptable range. Among terrestrial organisms, some insects are known to change their flight/walking speeds depending on light intensity; they reduce speeds under low light conditions (Menzel 1981, Spiewok \&
Schmolz 2006, Narendra et al. 2013, Reber et al. 2015). This is explained in relation to the temporal summation of neural responses in visual systems. Under dim light, where the absolute number of photons is small, temporal resolution of vision decreases because animal visual systems are thought to temporally integrate visual signals to improve the signal-to-noise ratio. One of the solutions to this is to slow down movement speeds, which enables the animals to maintain the rate of information gained per unit of travelling distance (Spiewok \& Schmolz 
2006, Reber et al. 2015). Such a relationship between ambient light intensity and movement speeds is expected for all visual systems in principle (cf. Warrant 1999, Warrant \& Locket 2004; but also see Baird et al. 2015).

Diving seabirds, such as penguins, are generally considered to be visually guided in their foraging (Wilson et al. 1993, Cannell \& Cullen 1998, Zimmer et al. 2008, Regular et al. 2011), although some seabirds may use non-visual information according to circumstances (White et al. 2007, Regular et al. 2011, Martin \& Crawford 2015). Dive depths of seabirds are often reported to present diel changes, i.e. deep in diurnal dives and shallow in nocturnal dives, associated with ambient light intensity at depth and/or diel vertical migration of prey resulting from changes in underwater light conditions (e.g. Wilson et al. 1993, Regular et al. 2010). Thus, diving behaviours of seabirds are directly or indirectly affected by ambient light conditions. However, other fine-scale behavioural adjustments between diurnal and nocturnal dives are not yet fully understood.

The king penguin Aptenodytes patagonicus is a large avian diver often foraging at depths greater than $100 \mathrm{~m}$ (Williams 1995). Additionally, as central place foragers, they regularly commute between their breeding colonies and productive foraging areas such as frontal zones over several hundreds of kilometres (Bost et al. 1997, Pütz et al. 1998). Because these foraging trips can last for more than 1 wk during brooding periods (Bost et al. 1997, Charrassin \& Bost 2001), they spend both day and night at sea. A strong diel pattern of dive depth has been reported in king penguins; they rarely dive deeper than $40 \mathrm{~m}$ during nighttime, while often diving deeper than $100 \mathrm{~m}$ during daytime (Kooyman et al. 1992, Bost et al. 2002). Thus, they experience a wide variation in light intensity between diurnal and nocturnal dives, as well as within diurnal dives, of more than 5 orders of magnitude (Martin 1999, Bost et al. 2002). In the present study, we investigated diel changes of behaviours within dives in king penguins, using novel data sets of swim speed, acceleration and dive path. We analysed the change in swimming behaviours during diving in relation to the ambient light intensity experienced within each dive. We show how king penguins may adjust their underwater cruising speeds within a range reasonable for cost-efficient transit, depending on ambient light conditions.

\section{MATERIALS AND METHODS}

\section{Field study}

Field experiments were performed at Possession Island $\left(46^{\circ} 25^{\prime} \mathrm{S}, 51^{\circ} 45^{\prime} \mathrm{E}\right)$, Crozet Archipelago, South Indian Ocean, from late January to early March in 2011. Chick-rearing king penguins were spotted at their nesting site and caught at the edge of the colony (Baie du Marin, Grande Manchotière, 16000 pairs) just before departing for the sea after the return of their partner. We used a hooked pole to capture birds and a hood to decrease the stress of capture. Multichannel data loggers (W1000L-3MPD3GT, $166 \mathrm{~mm}$ in length, $26 \mathrm{~mm}$ in diameter, $132 \mathrm{~g}$ in air; Little Leonardo) were deployed on the lower back of the birds $(\mathrm{N}=9)$ with waterproof tape (Tesa tape, 4651; Tesa), stainless steel cables (4.5 $\mathrm{mm}$ in width, STB-

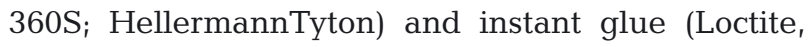
401; Henkel) to record diving behaviours during foraging trips at sea. The data loggers recorded depth based on ambient pressure (m), ambient temperature $\left({ }^{\circ} \mathrm{C}\right)$, swim speed $\left(\mathrm{m} \mathrm{s}^{-1}\right), 3$-axis magnetism $(\mathrm{nT})$ at $1 \mathrm{~Hz}$, and 3 -axis acceleration $\left(\mathrm{m} \mathrm{s}^{-2}\right)$ at $8 \mathrm{~Hz}$ for 2 birds and $16 \mathrm{~Hz}$ for the other birds (Table 1). For

Table 1. Summary of bio-logging data for instrumented king penguins Aptenodytes patagonicus at Crozet. Dates given as dd/mm/yy

\begin{tabular}{|c|c|c|c|c|c|c|c|c|c|c|c|}
\hline $\begin{array}{l}\text { Bird } \\
\text { ID }\end{array}$ & First dive & $\begin{array}{l}\text { Date and time (h) } \\
\text { Recapture }\end{array}$ & Last recording & $\begin{array}{c}\text { Trip } \\
\text { length (d) }\end{array}$ & $\begin{array}{c}\text { Data } \\
\text { length (d) }\end{array}$ & $\begin{array}{l}\text { Data length/ } \\
\text { trip length }\end{array}$ & $\begin{array}{c}\text { No. of } \\
\text { dives }\end{array}$ & $\begin{array}{c}\text { Longest } \\
\text { dive (min) }\end{array}$ & $\begin{array}{l}\text { Deepest } \\
\text { dive }(m)\end{array}$ & $\begin{array}{l}\text { Dive } \\
\text { path }\end{array}$ & Notes \\
\hline K1 & 27/01/11 01:00 & 08/02/11 12:00 & 02/02/11 18:00 & 12.5 & 6.7 & 0.54 & 1252 & 7.8 & 244.0 & Yes & \\
\hline K2 & 29/01/11 05:00 & 12/02/11 15:00 & 05/02/11 06:00 & 14 & 6.7 & 0.48 & 1311 & 7.0 & 241.5 & No & \\
\hline K3 & $30 / 01 / 11$ 13:00 & $21 / 02 / 11$ 19:00 & 05/02/11 23:00 & 22.3 & 6.4 & 0.29 & 1208 & 7.6 & 205.8 & Yes & GPS logger \\
\hline K4 & 29/01/11 19:00 & 09/02/11 12:00 & 06/02/11 03:00 & 10.7 & 7.3 & 0.68 & 1695 & 7.5 & 259.8 & Yes & \\
\hline K5 & $31 / 01 / 11$ 05:00 & $22 / 02 / 1117: 00$ & 06/02/11 14:00 & 22.5 & 6.1 & 0.27 & 1654 & 5.1 & 182.0 & Yes & GPS logger \\
\hline K6 & $12 / 02 / 1104: 00$ & 23/02/11 19:00 & 23/02/11 19:00 & 11.6 & 11.6 & 1.00 & 3346 & 8.4 & 318.0 & Yes & Acc. at $8 \mathrm{~Hz}$ \\
\hline K7 & - & - & - & - & - & - & - & - & - & - & No trip \\
\hline K8 & 18/02/11 12:00 & 03/03/11 14:00 & $25 / 02 / 11$ 18:00 & 17.0 & $7.3^{\mathrm{a}}$ & 0.43 & 1395 & 7.6 & 272.8 & No & Oesophagus logger \\
\hline K9 & 17/02/11 16:00 & 04/03/11 09:00 & 02/03/11 13:00 & 14.7 & 12.9 & 0.88 & 3648 & 9.7 & 366.2 & Yes & Acc. at $8 \mathrm{~Hz}$ \\
\hline
\end{tabular}


2 birds, a GPS data logger (CatTrack, recustomized with a $1500 \mathrm{mAh}$ lithium-iron phosphate battery and a deep depth casting; final size was ca. $60 \times 40 \times$ $25 \mathrm{~mm}, 50 \mathrm{~g}$ in air) was also deployed on the upper back (Table 1). These GPS tracking data were not used in this paper. For another bird, an oesophageal temperature logger was also deployed in addition to the multi-channel data logger, of which a temperature sensor was placed in the oesophagus and the body of the logger itself was inserted into the stomach (see methods in Charrassin et al. 2001) (Table 1). After deploying the loggers, all birds were released at the beach from which they departed. The birds were recaptured after their return from foraging at sea, and the data loggers and attachment tape were removed.

\section{Data processing}

Data were analysed using IGOR Pro (WaveMetrics) with the program package Ethographer (Sakamoto et al. 2009) and R (R Core Team 2014).

Dives were defined as submerging deeper than $2 \mathrm{~m}$ for longer than $30 \mathrm{~s}$, and shallow dives corresponded to dives $<40 \mathrm{~m}$ depth (Charrassin et al. 2002). Nocturnal dives were defined as dives that started during periods between $1 \mathrm{~h}$ after sunset and $1 \mathrm{~h}$ before sunrise. Sunrise and sunset times, which are defined as times of day when the top of the sun is on the horizon, were downloaded from the Hydrographic and Oceanographic Department of Japan Coast Guard website (www1.kaiho.mlit.go.jp/KOHO/ automail/sun_form3.html). For sunset and sunrise times, those at the breeding colony for the corresponding dates were used because it was not possible to estimate accurate positions of king penguins at sea from our data sets. As variations of sunrise/sunset times within a potential range of trips are less than 20 min (Fig. S1 in the Supplement at www.int-res. com/articles/suppl/m561p233_supp.pdf), we consider that the use of data for the geographic position of the colony did not influence the results.

Swim speeds relative to water were recorded as the number of rotations of an external propeller on the data logger $\left(\mathrm{rev} \mathrm{s}^{-1}\right)$, which was converted to absolute speeds $\left(\mathrm{m} \mathrm{s}^{-1}\right)$ using a constant value. The value of the constant was chosen so that depth profiles calculated from swim speeds and pitch angles at each time became consistent with actual depth profiles measured by a pressure sensor (Shiomi et al. 2008). Resolution of swim speed data corresponding to 1 rotation of the propeller ranged from 0.019 to $0.025 \mathrm{~m} \mathrm{~s}^{-1}$.
After the data conversion, mean swim speed within a dive was calculated. Because the rotation of the propeller seemed to slow or stop in some dives, which was seen as inconsistent with acceleration data presenting continuous strokes, dives with mean swim speed below a threshold of $1.0 \mathrm{~m} \mathrm{~s}^{-1}$ were excluded from the further analyses. The threshold was determined by visually checking a plot of average swim speed against stroke rate within a dive.

Three-dimensional dive paths were calculated with a customized macro available online (Narazaki \& Shiomi 2010, Shiomi et al. 2010) using the data of magnetism, acceleration derived from gravity, swim speed and depth (Johnson \& Tyack 2003, Shiomi et al. 2008). For that purpose, gravitational components of acceleration were extracted by a low-pass filter with a threshold value of $0.5 \mathrm{~Hz}$. From the reconstructed dive paths, horizontal travel distance and straight-line distance from the start to the end points of each dive were calculated.

King penguins performed flipper stroke-and-glide swimming. As an index of muscle workload during a dive, the number of strokes was calculated using the longitudinal acceleration data (cf. van Dam et al. 2002, Williams et al. 2004). First, by removing the component of gravitational acceleration from the longitudinal acceleration data, it was possible to obtain the dynamic part of the acceleration caused by body movements and changes of swimming speed. Then, total number of strokes per dive was measured by counting regular peaks in the dynamic acceleration data on the longitudinal axis, which reflect stroking activity associated with the change of propulsive forces (Shiomi et al. 2012). We defined a set of upand down-beats as 1 flipper stroke.

Data from the oesophageal temperature logger on bird K8 were used to measure feeding activities during shallow dives. Decreases in oesophageal temperature are considered a reliable index of feeding events (Charrassin et al. 2001). Defining a change of $-0.06^{\circ} \mathrm{C} \mathrm{s}^{-1}$ in oesophageal temperature as a threshold to extract the feeding events (cf. Charrassin et al. 2001), the number of feeding dives was counted in bird K8. We defined abrupt drops of swim speed by values $<-0.4 \mathrm{~m} \mathrm{~s}^{-2}$ (cf. Ropert-Coudert et al. 2000) as related to feeding events (see 'Results').

\section{Statistical analyses}

To examine whether diving behaviours were different between day and night, mixed model approaches were applied. Two models with and with- 
out day/night effect as a fixed factor were fitted to each combination of parameters from each individual. In all models, date of each dive was included as a categorical random factor. Then, a parsimonious model was determined by comparing Akaike's information criterion (AIC) values of the 2 models. Parameters and types of applied models are listed in Table 2. We used the lmer and the glmer functions in R package 'Ime4' (Bates et al. 2014) for linear mixed model and generalized linear mixed model analyses, respectively; for non-linear mixed model analyses, the non-linear mixed effect (nlme) function in $\mathrm{R}$ package 'nlme' (Pinheiro et al. 2014) was used.

\section{Diel change in diving behaviours}

To quantitatively investigate the diel changes in swim speeds, a double-sigmoid model (see Eq. 1) was fitted to mean swim speeds $\left(S_{\text {mean }}\right)$ against times of day at the start of each dive $(T)$ using the nlme function in R package 'nlme' (Pinheiro et al. 2014):

$$
\begin{aligned}
S_{\text {mean }} & =S_{\mathrm{n}}+S_{\mathrm{d}} /\left\{1+\exp \left[\left(t_{1}-T\right) / C_{1}\right]\right\} \\
& -S_{\mathrm{d}} /\left\{1+\exp \left[\left(t_{2}-T\right) / C_{2}\right]\right\}
\end{aligned}
$$

where $s_{\mathrm{d}}$ is the asymptotic height, corresponding to an estimate of the difference of mean swim speeds between nocturnal and diurnal dives, $s_{n}$ is the mean swim speed in nocturnal dives, $t_{1}$ and $t_{2}$ are the times during the day at which mean swim speed reaches the middle values between nocturnal and diurnal speeds, and $c_{1}$ and $c_{2}$ are the steepness factors, corresponding to the time elapsed between reaching $1 / 2$ and $3 / 4$ of $s_{\mathrm{d}}$. This model is modified from the one used by Bunnefeld et al. (2011). For comparison, the same model was also applied to dive depths $\left(D_{\max }\right)$ against $T$ :

$$
\begin{aligned}
D_{\max } & =d_{\mathrm{n}}+d_{\mathrm{d}} /\left\{1+\exp \left[\left(t_{3}-T\right) / c_{3}\right]\right\} \\
& -d_{\mathrm{d}} /\left\{1+\exp \left[\left(t_{4}-T\right) / c_{4}\right]\right\}
\end{aligned}
$$

where $d_{\mathrm{d}}$ is the asymptotic height, corresponding with an estimate of the difference in mean dive depths between nocturnal and diurnal dives, and $d_{n}$ is the mean dive depth in nocturnal dives. Coefficients $t_{3}, t_{4}, c_{3}$ and $c_{4}$ have the same meaning as $t_{1}, t_{2}$, $c_{1}$ and $c_{2}$, respectively. Note that only dives deeper than $40 \mathrm{~m}$ were used for twilight and daylight periods in this regression analysis, because changes of the upper limit of dive depth around dawn and dusk were the focus of this study.

\section{Diel change in light intensity}

To study vertical and temporal variation in light levels experienced in each dive, underwater light intensity was estimated by an astronomical model, following Regular et al. (2011). This model was based on Iqbal (1984) for estimation of solar irradiance and on Jensen et al. (2001) for estimation of lunar and star irradiance at night. Results of this model calculation were previously validated with data of light intensity measured by a light sensor on diving birds (Regular et al. 2011). In the present study, the light level at the maximum depth reached within each dive was calculated as a function of date, time of day and depth. We used an attenuation coefficient of 0.03, which was the average value measured by light sensors on southern elephant seals at sea around Kerguelen Island, i.e. near our field site (Jaud et al. 2012). The coefficient to include effects of atmospheric absorption of light was determined as 0.25 , which means that $1 / 4$ of the light above the atmosphere is assumed to reach the Earth's surface. This coefficient affects absolute values of estimation but not relative relationships of values between diurnal and nocturnal dives. Note that because the model does not cope with twilight periods, only diurnal and nocturnal dives were used

\begin{tabular}{|c|c|c|c|}
\hline Model ID & Dependent variable $(Y)$ & Fixed effect $(X)$ & Type of model \\
\hline Model 1 & Mean swim speed & & Linear mixed model $(Y=b)$ \\
\hline Model 2 & Total no. of strokes & & $\begin{array}{l}\text { Generalized linear mixed model (error distribution }= \\
\text { Poisson, } \log \text { link function, offset }=\ln (\text { dive duration })) \\
(Y=\exp (b+\text { offset }))\end{array}$ \\
\hline Model 3 & Dive duration & Dive depth & Non-linear mixed model $\left(Y=a X^{b}\right)$ \\
\hline Model 4 & Straight-line distance & Travelled horizontal distance & Non-linear mixed model $\left(Y=a X^{b}\right)$ \\
\hline
\end{tabular}
for this analysis.

Table 2. Summary of the models fitted to examine differences between diurnal and nocturnal diving behaviours. Estimated coefficients are presented as $a$ and $b$. All models include day/night as a fixed effect and date as a random factor for coefficient $b$ 


\section{RESULTS}

For 6 of the 9 instrumented birds, all the parameters were successfully recorded; for 2 other birds, all the data except magnetism were obtained, i.e. dive paths could not be calculated; another bird did not leave the colony and was excluded from the dataset (Table 1). The data from 1 bird (K6) covered a whole trip, while those from the other birds covered around 30 to $90 \%$ of the foraging trip (Table 1). One of the birds (K9) recorded both the longest (9.7 $\mathrm{min}$ ) and the deepest (366.2 $\mathrm{m}$ ) dives among those reported for this species in summer.

\section{Diel change in diving behaviours}

Of all dives recorded during the $24 \mathrm{~h}$ diel cycle, $71 \pm 11 \%$ (mean $\pm \mathrm{SD}, \mathrm{N}=8$ birds) of dives in each bird were diurnal, $20 \pm 11 \%$ nocturnal and $9 \pm 2 \%$ during twilight periods. During the night, the mean diving depth of each bird was 5.6 to $19.9 \mathrm{~m}$, and all except for a few dives were shallower than $40 \mathrm{~m}$. During the day, there were dives both deeper and shallower than $100 \mathrm{~m}_{i}$ most of the latter were shallower than $40 \mathrm{~m}$, similar to nocturnal dives (Fig. 1). Dive depths gradually increased during dawn and decreased during dusk (Fig. 1).
Fig. 1. Example data of dive depth (maximum depth reached; O) and mean swim speed $(\Delta)$ in each dive plotted against the starting time of the dive. Light grey zones indicate twilight periods, and darker grey indicates night
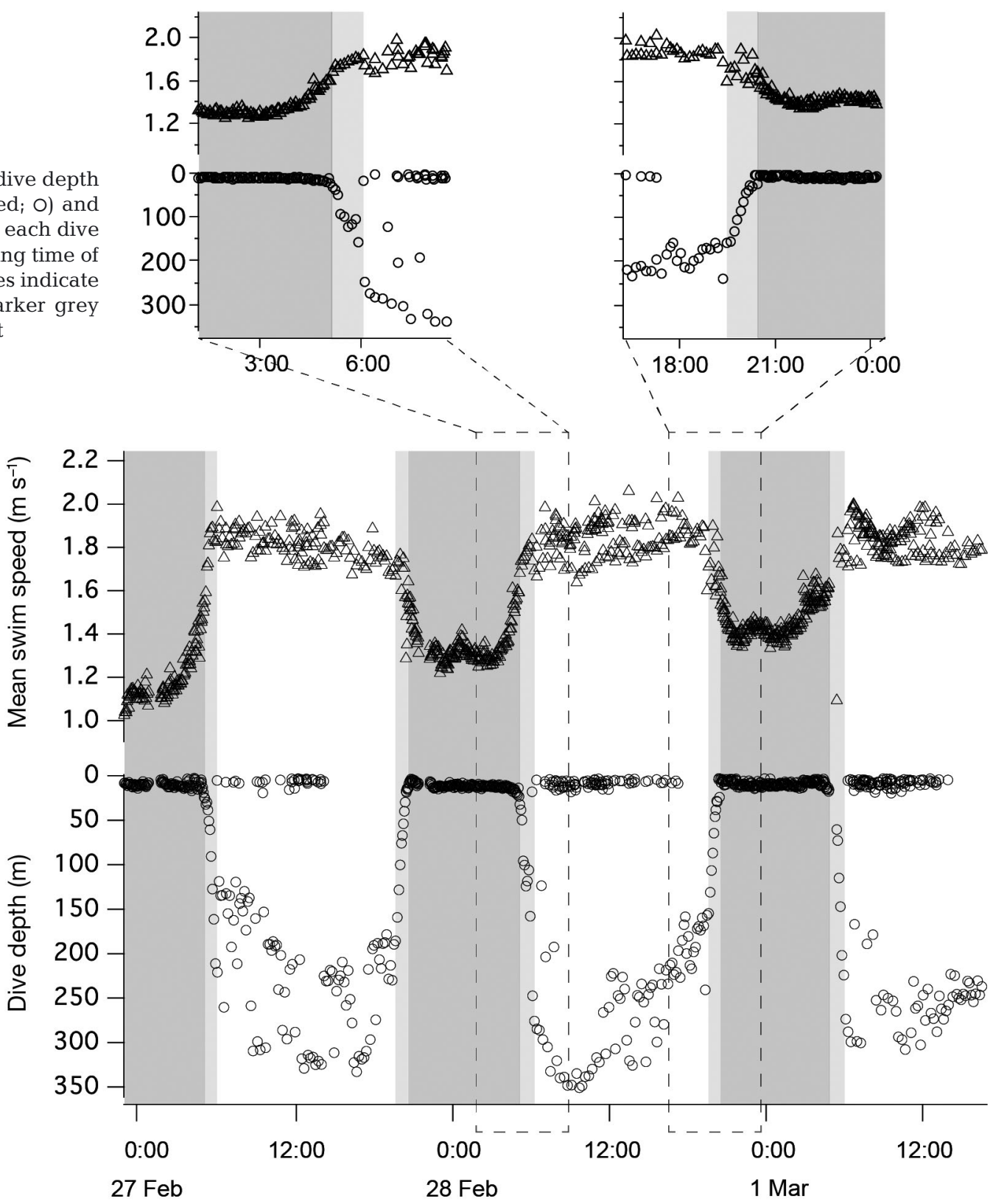


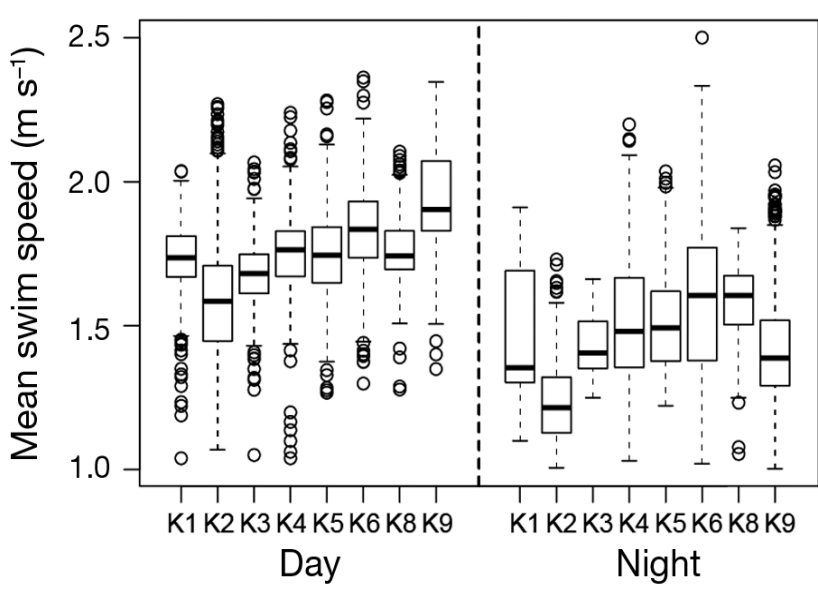

Fig. 2. Box plots of mean swim speeds in diurnal shallow and nocturnal shallow dives for each individual $(\mathrm{N}=8 \mathrm{birds}$, see Table 1). Bottom and top of each box correspond to lower and upper quartile values, respectively. Black horizontal line within each box represents the median. Whiskers represent 1.5 times the interquartile range, and circles indicate outliers beyond this range

Swim speeds also showed diel patterns (Fig. 1). Swim speeds within a shallow dive were relatively constant, while those in deep dives dramatically varied at depth (see Ropert-Coudert et al. 2000 for details). Therefore, only shallow dives were used when comparing day and night behaviours. Mean swim speed in each shallow dive was lower at night than in the day for all birds (mean difference: $0.3 \pm$ $0.10 \mathrm{~m} \mathrm{~s}^{-1}$; grand mean speed: $1.7 \pm 0.07 \mathrm{~m} \mathrm{~s}^{-1}$ vs. $1.4 \pm 0.10 \mathrm{~m} \mathrm{~s}^{-1}$; Fig. 2, Table 3, Tables S1 \& S2 in the Supplement at www.int-res.com/articles/suppl/ m561p233_supp.pdf). Swim speeds gradually increased towards the daytime and decreased towards nighttime, respectively (Figs. $1 \& 3$ ).

The double-sigmoid models showed temporal patterns of both mean swim speeds and dive depths: both parameters increased around sunrise

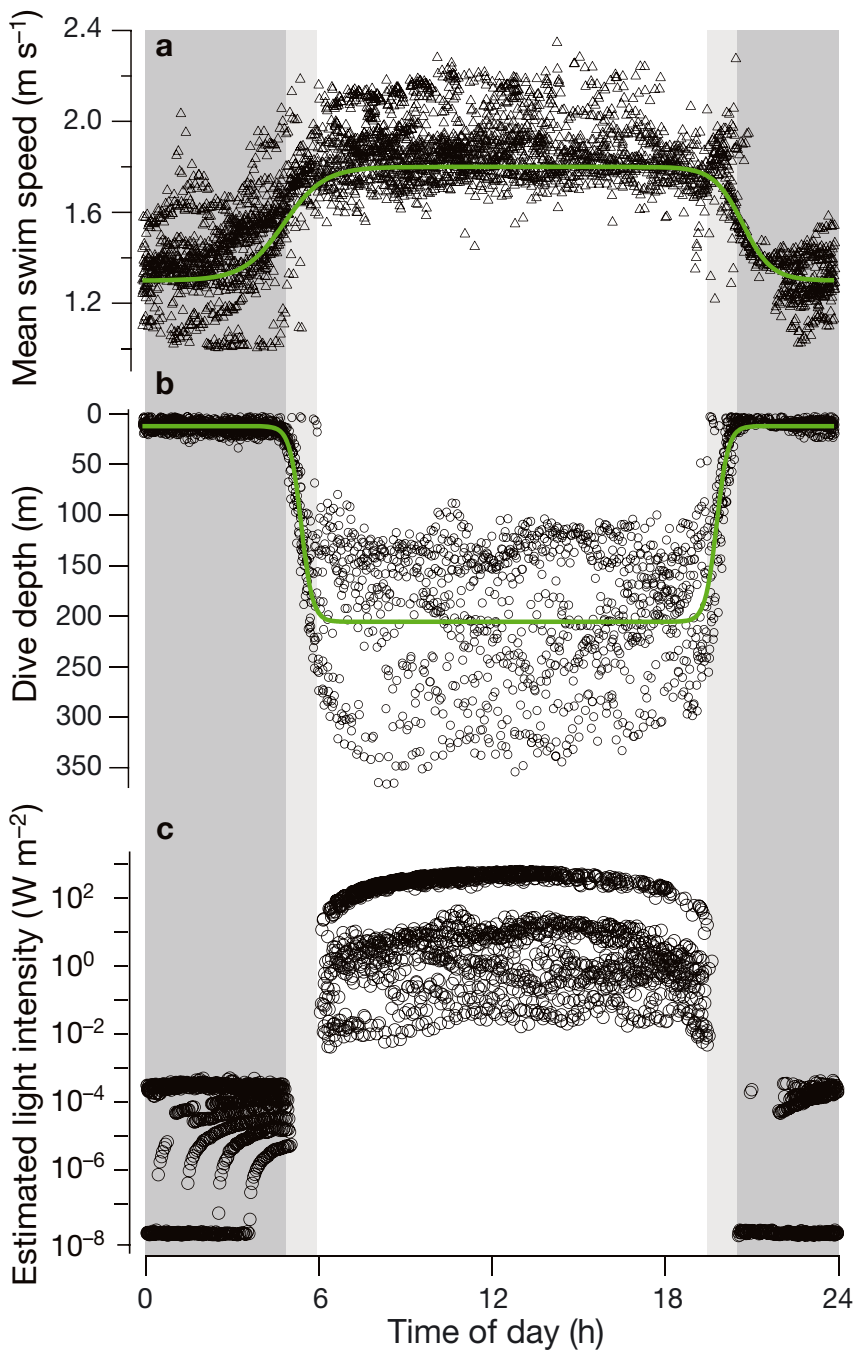

Fig. 3. (a) Mean swim speeds, (b) dive depths and (c) estimated light intensity at the maximum depth in each dive plotted against time of day for bird K9. Light grey zones indicate twilight periods, and dark grey indicates night. Green lines represent the double-sigmoid models fitted by a non-linear mixed model approach. Note that for diurnal and twilight dives in (b), only dives deeper than $40 \mathrm{~m}$ were used, because the upper limit was the main focus

Table 3. Swim speed and stroke rate estimated with mixed models for each individual. Swim speeds were estimated as the intercept of Model 1, and stroke rates as the slope of Model 2 (see Table 2, Fig. 4a)

\begin{tabular}{|c|c|c|c|c|c|c|c|c|c|}
\hline \multirow{2}{*}{$\begin{array}{l}\text { Bird } \\
\text { ID }\end{array}$} & \multirow{2}{*}{$\begin{array}{l}\text { Body mass } \\
\quad(\mathrm{kg})\end{array}$} & \multicolumn{3}{|c|}{$\longrightarrow$ No. of dives -} & \multicolumn{3}{|c|}{- Swim speed $\left(\mathrm{m} \mathrm{s}^{-1}\right) \longrightarrow$} & \multicolumn{2}{|c|}{ Stroke rate $(\mathrm{Hz})$} \\
\hline & & $\begin{array}{l}\text { Deep } \\
\text { day }\end{array}$ & $\begin{array}{c}\text { Shallow } \\
\text { day }\end{array}$ & $\begin{array}{c}\text { Shallow } \\
\text { night }\end{array}$ & $\begin{array}{l}\text { Deep day } \\
\text { mean }\end{array}$ & $\begin{array}{c}\text { Shallow day } \\
\text { mean }\end{array}$ & $\begin{array}{l}\text { Shallow night } \\
\text { mean }\end{array}$ & $\begin{array}{c}\text { Shallow } \\
\text { day }\end{array}$ & $\begin{array}{c}\text { Shallow } \\
\text { night }\end{array}$ \\
\hline K1 & 12.1 & 135 & 893 & 45 & 1.8 & 1.7 & 1.4 & 0.79 & 0.64 \\
\hline K2 & 10.9 & 326 & 554 & 182 & 1.8 & 1.6 & 1.3 & 0.70 & 0.55 \\
\hline K3 & 9.3 & 317 & 669 & 99 & 1.7 & 1.6 & 1.4 & 0.84 & 0.64 \\
\hline K4 & 11.5 & 529 & 560 & 411 & 1.8 & 1.8 & 1.4 & 0.76 & 0.60 \\
\hline K5 & 10.3 & 249 & 994 & 243 & 1.8 & 1.7 & 1.5 & 0.94 & 0.76 \\
\hline K6 & 10.7 & 654 & 1519 & 918 & 1.8 & 1.8 & 1.5 & 0.83 & 0.68 \\
\hline K8 & 8.9 & 794 & 204 & 283 & 1.9 & 1.7 & 1.6 & 0.83 & 0.72 \\
\hline K9 & 11.3 & 1104 & 889 & 1377 & 1.8 & 1.8 & 1.4 & 0.91 & 0.59 \\
\hline Mean & 10.6 & & & & 1.8 & 1.7 & 1.4 & 0.82 & 0.65 \\
\hline
\end{tabular}


Table 4. Estimates of coefficients obtained by fitting double-sigmoid models to mean swim speeds and dive depths against time of day (see Fig. 3a,b). Blanks mean that it was not possible to estimate coefficients due to lack of data for some times of day. Note that the number of dives analysed differs between mean swim speed and dive depth because different numbers of dives were excluded from each analysis, due to stalling of a propeller for swim speeds and shallow dives during daylight and twilight periods for dive depths (see text for details)

\begin{tabular}{|c|c|c|c|c|c|c|c|c|c|c|c|c|c|c|}
\hline \multirow{2}{*}{$\begin{array}{l}\text { Bird } \\
\text { ID }\end{array}$} & \multirow{2}{*}{$\begin{array}{l}\text { No. of } \\
\text { dives }\end{array}$} & \multicolumn{6}{|c|}{-Mean swim speed } & \multirow{2}{*}{$\begin{array}{l}\text { No. of } \\
\text { dives }\end{array}$} & \multicolumn{6}{|c|}{-Dive depth- } \\
\hline & & $S_{\mathrm{n}}$ & $S_{\mathrm{d}}$ & $t_{1}$ & $t_{2}$ & $C_{1}$ & $C_{2}$ & & $d_{\mathrm{n}}$ & $d_{\mathrm{d}}$ & $t_{3}$ & $t_{4}$ & $C_{3}$ & $C_{4}$ \\
\hline K1 & 1140 & & & & & & & 251 & & & & & & \\
\hline K2 & 1202 & 1.2 & 0.5 & 4.5 & 21.3 & 0.2 & 0.1 & 702 & 10.6 & 131.2 & 4.8 & 20.7 & 0.2 & 0.2 \\
\hline K3 & 1207 & 1.4 & 0.3 & 4.6 & 21.4 & 0.2 & 0.2 & 503 & & & & & & \\
\hline K4 & 1658 & & & & & & & 1081 & 10.9 & 157.5 & 4.8 & 20.6 & 0.2 & 0.2 \\
\hline K5 & 1651 & & & & & & & 535 & 5.8 & 97.2 & 5.4 & 20.8 & 0.5 & 0.2 \\
\hline K6 & 3319 & 1.4 & 0.4 & 4.5 & 21.6 & 0.4 & 0.8 & 1727 & 11.8 & 176.8 & 5.3 & 20.2 & 0.2 & 0.2 \\
\hline K8 & 1390 & 1.4 & 0.5 & 5.2 & 20.6 & 0.4 & 0.4 & 1168 & 17.8 & 140.4 & 5.2 & 20.0 & 0.2 & 0.3 \\
\hline K9 & 3613 & 1.3 & 0.5 & 4.9 & 20.8 & 0.7 & 0.5 & 2682 & 12.1 & 193.5 & 5.5 & 19.9 & 0.2 & 0.2 \\
\hline Mean & & 1.3 & 0.4 & 4.7 & 21.2 & 0.4 & 0.4 & & 11.5 & 149.4 & 5.2 & 20.4 & 0.3 & 0.2 \\
\hline
\end{tabular}
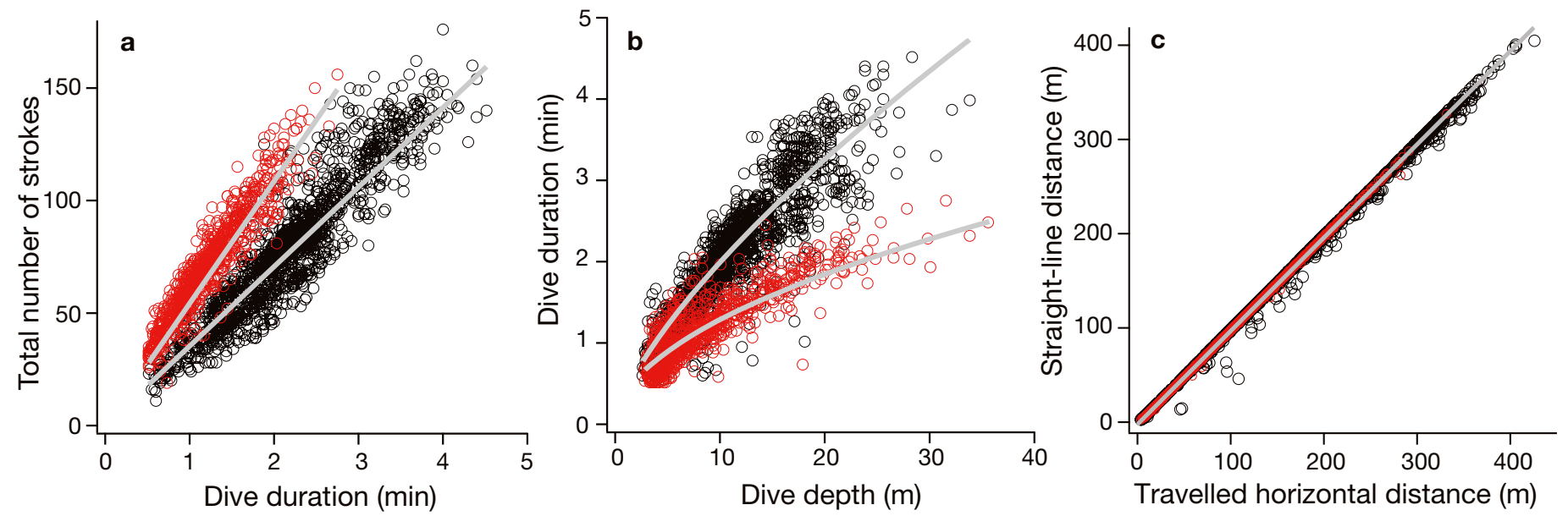

Fig. 4. Relationships between (a) total number of strokes in a shallow dive and dive duration, (b) dive duration and dive depth, and (c) straight-line and travelled horizontal distance from the start to the end of each dive for bird K9. Diurnal shallow dives $(\mathrm{O})$ and nocturnal shallow dives (O) are shown. Grey lines show fitted models for each relationship (see Table S2 in the Supplement at www.int-res.com/articles/suppl/m561p233_supp.pdf)

and decreased around sunset, respectively (Fig. 3a,b, Table 4). However, swim speeds started to increase earlier and to decrease later than dive depth, according to the estimated coefficients $t_{1-4}$ (Table 4). In most cases, rates of change during these transition periods (coefficients $C_{1-4}$ ) were smaller in the models for swim speeds (Table 4).

Characteristics of flipper stroke activities during diurnal and nocturnal shallow dives corresponded with those of swim speeds. Thus the total numbers of strokes during dives were smaller at night (for a given dive duration), indicating a lower stroke rate (Fig. 4a, Table 3). For all except 1 individual, dive durations to a given depth were longer in nocturnal dives (Fig. 4b, Tables S1 \& S2).

\section{Dive paths and oesophageal temperature in shallow dives}

Estimated dive paths of the 6 birds during shallow dives showed that the maximum horizontal distance king penguins could travel in a typical shallow dive was around $400 \mathrm{~m}$ (Fig. 4c). Estimated exponents of the mixed models for the relationship between straight line and travelled distance were nearly equal to 1.0 (range 0.92 to 0.96 ; Table S2), which means that the birds swam horizontally on a nearly perfect straight line. A significant effect of day/night was not found, except for 1 bird (Table S1).

In dives of the bird for which oesophageal temperature was recorded (K8), drops of temperature, 

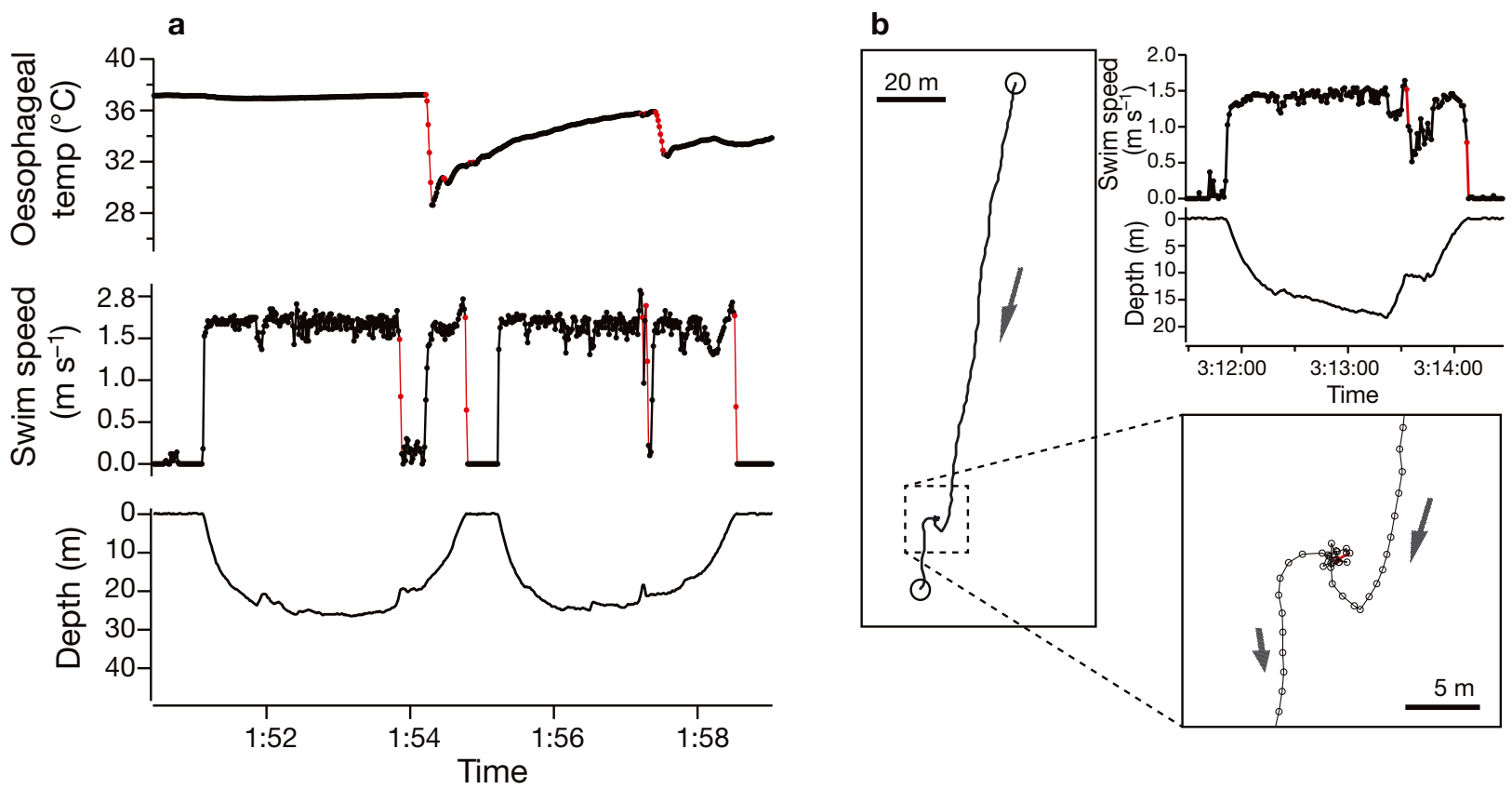

Fig. 5. (a) Time-series data of oesophageal temperature, swim speed and depth in bird K8 and (b) horizontal paths and time series data of swim speed and depth in a nocturnal dive of bird K9 when rapid decrease in swim speeds occurred. In (b), circles indicate the start and end points of the dive, arrows indicate travelling direction and red points indicate the data where rate of changes in swim speeds was below $-0.4 \mathrm{~m} \mathrm{~s}^{-2}$

i.e. the signal of feeding events, were observed in some shallow dives (Fig. 5a). Of the 17 shallow dives in which such temperature decreases occurred, 14 were nocturnal. The dives associated with oesophageal temperature decreases for this bird corresponded to $4.9 \%$ of all the nocturnal dives recorded during its foraging trip. Among these 14 dives, 13 also showed rapid and short drop in swim speed (Fig. 5a). Such drops in swim speed occurred in $12.7 \%$ (36 dives) of the nocturnal dives in bird K8, while swim speeds were basically kept constant within nocturnal dives as well as diurnal shallow dives. Rapid decreases in swim speeds were also observed in 2.0 to $12.6 \%$ of nocturnal shallow dives in the other individuals. On the few nocturnal dives where that occurred, dive paths concurrently became tortuous (Fig. 5b).

\section{Diel change in estimated light intensity}

According to the astronomical model, light intensity experienced in each dive varied from $10^{-8}$ to $10^{-3}$ $\mathrm{W} \mathrm{m}{ }^{-2}$ at night and from $10^{-2}$ to $10^{3} \mathrm{~W} \mathrm{~m}^{-2}$ in the day (Fig. 3c). In deep dives during daylight hours, even to $>300 \mathrm{~m}$, light intensities were still higher than those in nocturnal shallow dives.

\section{DISCUSSION}

The present study revealed strong diel patterns in diving behaviours of king penguins, not only in dive depth but also in swim speed, stroke rate and dive duration. The nocturnal dive depths were limited to shallow water, in agreement with previous studies (Kooyman et al. 1992, Bost et al. 2002), and the birds swam more slowly with a lower stroke rate at night for longer dive durations. Some diving mammals have been reported to decrease their swim speeds in nocturnal dives, but the differences were observed during the bottom phases, i.e. foraging (e.g. Baikal seals, Watanabe et al. 2004; sperm whales, Aoki et al. 2007). These changes were, therefore, interpreted as optimization of foraging behaviour following a diurnal shift of prey species and/or changes in prey density, based on a theoretical model (Wilson et al. 2002). In king penguins, a decrease in swim speeds is likely to be attributable to a different reason. Their swim speeds were indeed lower at night compared to those during the day, not only during the bottom phase but throughout the entirety of a nocturnal dive. In addition, horizontally straight paths in their shallow dives indicated that the main function of these dives was transit rather than foraging, both in the day and at night. 
As the main foraging area of king penguins is the Polar Front Zone, about $400 \mathrm{~km}$ from their colony (Bost et al. 2009), they are expected to have a strong motivation for horizontal movements between the destination of the foraging trips and the breeding island. The number of feeding events recorded as rapid changes in oesophageal temperature and/or swim speeds showed that they caught prey during nocturnal shallow dives, but only occasionally. Previous studies presented similar evidence that feeding in shallow water occurs in only a small proportion of nocturnal dives (Pütz \& Bost 1994). The bulk of king penguin diet consists of myctophid fish during the summer season (Cherel \& Ridoux 1992), and these small, mesopelagic fish are known to perform diel vertical migration (Perissinotto \& McQuaid 1992, Collins et al. 2008). During daylight hours, they aggregate and rest mostly at great depths, i.e. $>100 \mathrm{~m}$. At night, myctophids actively disperse to near-surface waters in large numbers (Perissinotto \& McQuaid 1992, Collins et al. 2008), although prey species of king penguins occupy only a small part of fish biomass in shallow water at night $(0.2 \%$; Bost et al. 2002). The main prey fish for king penguins is likely to have photophores (Bost et al. 2002), but it is expected to reduce intensity of bioluminescence during the night because the main function of photophores in myctophids is to camouflage their bodies from below by counter-illumination (Case et al. 1977). This high activity and low visibility of prey at night are probably the reasons why feeding in nocturnal shallow dives is rare in king penguins and why they mainly forage in diurnal deep dives (Pütz \& Bost 1994, Bost et al. 2002).

King penguins have eye structures adapted to the dim light experienced at depth and at night, as their eye size is relatively large and their pupil can expand 300 times larger in the dark than the smallest size during the daylight (Martin 1999). However, as light levels experienced in nocturnal dives were estimated to be much lower than those in diurnal dives, even when reaching 100 to $300 \mathrm{~m}$ depth, additional behavioural adjustments should be adaptive. The difference in mean cruising speeds between diurnal and nocturnal shallow dives (1.7 vs. $1.4 \mathrm{~m} \mathrm{~s}^{-1}$ on average in this study) means that, when the birds swam at night, it took about 1.2 times longer to travel a given distance than when swimming during the day. During travelling and opportunistic feeding in darkness, lower swim speeds would be beneficial, maintaining the rate of information gained per unit of travelling distance despite the temporal integration of visual signals.
Gradual decreases and increases in mean swim speeds, as well as differences in underwater light intensities between day and night, support the hypothesis that changes in swim speeds are linked with ambient light conditions. To date, such temporal transitions in swim speeds have not been documented in any aquatic animals. Swim speeds did not start to shift at the same time as the dive depths, but started to increase earlier in the morning and to decrease later at night than did dive depths. Thus, it would appear that light intensity, either via a threshold or an intensity-linked mechanism, might modulate both swim speeds and dive depths. For example, light intensity itself and diel vertical migration of prey following changes in light intensity may trigger the observed shift of swim speeds and dive depths, respectively. In either case, these temporal patterns indicate that king penguins adjust their swim speeds in response to changes in ambient light conditions.

The lower stroke rate found in nocturnal shallow dives further confirmed king penguins actively changed their locomotion patterns between day and night, resulting in a difference in swim speeds. As an additional effect of the slower swimming at night, the lower mechanical cost per unit of time with the lower stroke rate could prolong dive duration (cf. Hindell et al. 2000). Thus, the longer depth-specific dive durations of night dives (in 6 of the 8 studied birds) seem to stem from reduced power costs due to the lower swim speeds (Culik et al. 1996), which themselves may compensate for the shorter travelling distance per second with lower swim speeds under the limited light conditions. In the congeneric emperor penguin Aptenodytes forsteri, the durations until starting to return to the water surface are also longer when the penguins swim at lower stroke rate (Shiomi et al. 2012). These data indicate a trade-off between dive duration and rate of energy consumption in avian air breather foragers with limited oxygen stores.

To conclude, this study showed diel shifts in swim speeds of king penguins. They may adjust their swim speeds within a range reasonable for cost-efficient transit, depending on ambient light conditions. To date, this phenomenon has not been studied in any marine diving animals, although it is well known in some insects. Future studies may provide evidence that this behaviour is common in other marine taxa.

Acknowledgements. We are grateful to all the members of the mission 48 in the Crozet Archipelago, especially Marguerite Netchaieff, Astrid Willener and Antoine Joris for their field assistance. We also thank Ken Yoda and Dale M. 
Kikuchi for helpful comments to improve the early draft, Eric Warrant for his advice related to animal vision, Paul Regular for his help to calculate underwater irradiance using the astronomical model, Itsumi Nakamura and Kagari Aoki for their help to process magnetism data, Jayson Semmens for English editing, and 3 anonymous reviewers for helpful and constructive comments. This study was financially supported by the Institut Polaire Français Paul-Emile Victor (IPEV, programme no. 394, resp.: C.A.Bost), the Terres Australes et Antarctiques Françaises administration, Bio-Logging Science at the University of Tokyo (UTBLS), Research Fellowships of the Japan Society for the Promotion of Science (JSPS) for Young Scientists (K.Shiomi; 23-2916), JSPS Postdoctoral Fellowships for Research Abroad (K.Shiomi; 25-360) and the Grant-in-Aid for Scientific Research from JSPS (K.Sato; 25660152). All procedures were reviewed and permitted by the ethics committee of the French Polar Institute (IPEV), and the French Environment Ministry and Office for Life Science Research Ethics and Safety, University of Tokyo (no. P10-26).

\section{LITERATURE CITED}

Aoki K, Amano M, Yoshioka M, Mori K, Tokuda D, Miyazaki N (2007) Diel diving behavior of sperm whales off Japan. Mar Ecol Prog Ser 349:277-287

Baird E, Fernandez DC, Wcislo WT, Warrant EJ (2015) Flight control and landing precision in the nocturnal bee Megalopta is robust to large changes in light intensity. Front Physiol 6:305

Bates D, Maechler M, Bolker B, Walker S (2014) lme4: linear mixed-effects models using Eigen and S4. R package version 1.1-7. http://CRAN.R-project.org/package=lme4

Bost CA, Georges JY, Guinet C, Cherel Y and others (1997) Foraging habitat and food intake of satellite-tracked king penguins during the austral summer at Crozet Archipelago. Mar Ecol Prog Ser 150:21-33

Bost CA, Zorn T, Le Maho Y, Duhamel G (2002) Feeding of diving predators and diel vertical migration of prey: king penguins' diet versus trawl sampling at Kerguelen Islands. Mar Ecol Prog Ser 227:51-61

Bost CA, Cotte C, Bailleul F, Cherel Y and others (2009) The importance of oceanographic fronts to marine birds and mammals of the southern oceans. J Mar Syst 78:363-376

Bunnefeld N, Boerger L, van Moorter B, Rolandsen CM, Dettki H, Solberg EJ, Ericsson G (2011) A model-driven approach to quantify migration patterns: individual, regional and yearly differences. J Anim Ecol 80:466-476

* Cannell BL, Cullen JM (1998) The foraging behaviour of little penguins Eudyptula minor at different light levels. Ibis 140:467-471

Case JF, Warner J, Barnes AT, Lowenstine M (1977) Bioluminescence of lantern fish (Myctophidae) in response to changes in light intensity. Nature 265:179-181

* Charrassin JB, Bost CA (2001) Utilisation of the oceanic habitat by king penguins over the annual cycle. Mar Ecol Prog Ser 221:285-297

Charrassin JB, Kato A, Handrich Y, Sato K and others (2001) Feeding behaviour of free-ranging penguins determined by oesophageal temperature. Proc R Soc B 268:151-157

* Charrassin JB, Le Maho Y, Bost CA (2002) Seasonal changes in the diving parameters of king penguins (Aptenodytes patagonicus). Mar Biol 141:581-589

* Cherel Y, Ridoux V (1992) Prey species and nutritive value of food fed during summer to king penguin (Aptenodytes patagonica) chicks at Possession Island, Crozet Archipelago. Ibis 134:118-127

Collins MA, Xavier JC, Johnston NM, North AW and others (2008) Patterns in the distribution of myctophid fish in the northern Scotia Sea ecosystem. Polar Biol 31:837-851

* Culik BM, Pütz K, Wilson RP, Allers D, Lage J, Bost CA, Le Maho Y (1996) Diving energetics in king penguins (Aptenodytes patagonicus). J Exp Biol 199:973-983

* Hindell MA, Lea MA, Morrice MG, MacMahon CR (2000) Metabolic limits on dive duration and swimming speed in the southern elephant seal Mirounga leonina. Physiol Biochem Zool 73:790-798

Iqbal M (1984) An introduction to solar radiation. Academic Press, Toronto

Jaud T, Dragon AC, Garcia JV, Guinet C (2012) Relationship between chlorophyll a concentration, light attenuation and diving depth of the southern elephant seal Mirounga leonina. PLOS ONE 7:e47444

Jensen HW, Durand F, Stark MM, Premoze S, Dorsey J, Shirley P (2001) A physically-based night sky model. In: Pocock L (ed) Proceedings of the 28th annual conference on computer graphics and interactive techniques. ACM, New York, NY, p 399-408

Johnson MP, Tyack PL (2003) A digital acoustic recording tag for measuring the response of wild marine mammals to sound. IEEE J Oceanic Eng 28:3-12

Kooyman GL, Cherel Y, Le Maho Y, Croxall JP, Thorson PH, Ridoux V (1992) Diving behavior and energetics during foraging cycles in king penguins. Ecol Monogr 62:143-163

* Martin GR (1999) Eye structure and foraging in king penguins Aptenodytes patagonicus. Ibis 141:444-450

*Martin GR, Crawford R (2015) Reducing bycatch in gillnets: a sensory ecology perspective. Glob Ecol Conserv 3: $28-50$

Menzel R (1981) Achromatic vision in the honeybee at low light intensities. J Comp Physiol 141:389-393

Narazaki T, Shiomi K (2010) Reconstruction of 3-D path (ThreeD_path). http://bre.soc.i.kyoto-u.ac.jp/bls/index. php?3D_path

* Narendra A, Reid SF, Raderschall CA (2013) Navigational efficiency of nocturnal Myrmecia ants suffers at low light levels. PLOS ONE 8:e58801

Perissinotto R, McQuaid CD (1992) Land-based predator impact on vertically migrating zooplankton and micronekton advected to a Southern Ocean archipelago. Mar Ecol Prog Ser 80:15-27

Pinheiro J, Bates D, DebRoy S, Sarkar D, R Core Team (2014) nlme: linear and nonlinear mixed effects models. $\mathrm{R}$ package version 3.1-118. http://CRAN.R-project.org/ package $=$ nlme $\% 3 \mathrm{E}$

*Pütz K, Bost CA (1994) Feeding behavior of free-ranging king penguins (Aptenodytes patagonicus). Ecology 75: 489-497

* Pütz K, Wilson RP, Charrassin JB, Raclot T and others (1998) Foraging strategy of king penguins (Aptenodytes patagonicus) during summer at the Crozet Islands. Ecology 79 : 1905-1921

R Core Team (2014) R: a language and environment for statistical computing. R Foundation for Statistical Computing, Vienna

Reber T, Vahakainu A, Baird E, Weckstrom M, Warrant E, Dacke M (2015) Effect of light intensity on flight control and temporal properties of photoreceptors in bumblebees. J Exp Biol 218:1339-1346 
Regular PM, Davoren GK, Hedd A, Montevecchi WA (2010) Crepuscular foraging by a pursuit-diving seabird: tactics of common murres in response to the diel vertical migration of capelin. Mar Ecol Prog Ser 415:295-304

Regular PM, Hedd A, Montevecchi WA (2011) Fishing in the dark: a pursuit-diving seabird modifies foraging behaviour in response to nocturnal light levels. PLOS ONE 6: e26763

Ropert-Coudert Y, Sato K, Kato A, Charrassin JB, Bost CA, Le Maho Y, Naito Y (2000) Preliminary investigations of prey pursuit and capture by king penguins at sea. Polar Biosci 13:101-112

Sakamoto KQ, Sato K, Ishizuka M, Watanuki Y, Takahashi A, Daunt F, Wanless S (2009) Can ethograms be automatically generated using body acceleration data from freeranging birds? PLOS ONE 4:e5379

Shiomi K, Sato K, Mitamura H, Arai N, Naito Y, Ponganis PJ (2008) Effect of ocean current on the dead-reckoning estimation of 3-D dive paths of emperor penguins. Aquat Biol 3:265-270

Shiomi K, Narazaki T, Sato K, Shimatani K, Arai N, Ponganis PJ, Miyazaki N (2010) Data-processing artefacts in three-dimensional dive path reconstruction from geomagnetic and acceleration data. Aquat Biol 8:299-304

Shiomi K, Sato K, Ponganis PJ (2012) Point of no return in diving emperor penguins: Is the timing of the decision to return limited by the number of strokes? J Exp Biol 215: 135-140

Spiewok S, Schmolz E (2006) Changes in temperature and light alter the flight speed of hornets (Vespa crabro L.). Physiol Biochem Zool 79:188-193

Editorial responsibility: Rory Wilson, Swansea, UK van Dam RP, Ponganis PJ, Ponganis KV, Levenson DH, Marshall G (2002) Stroke frequencies of emperor penguins diving under sea ice. J Exp Biol 205:3769-3774

* Warrant EJ (1999) Seeing better at night: life style, eye design and the optimum strategy of spatial and temporal summation. Vision Res 39:1611-1630

* Warrant EJ, Locket NA (2004) Vision in the deep sea. Biol Rev Camb Philos Soc 79:671-712

*Watanabe Y, Baranov EA, Sato K, Naito Y, Miyazaki N (2004) Foraging tactics of Baikal seals differ between day and night. Mar Ecol Prog Ser 279:283-289

* White CR, Day N, Butler PJ, Martin GR (2007) Vision and foraging in cormorants: More like herons than hawks? PLOS ONE 2:e639

Williams TD (1995) The penguins. Oxford University Press, Oxford

Williams TM, Fuiman LA, Horning M, Davis RW (2004) The cost of foraging by a marine predator, the Weddell seal Leptonychotes weddellii: pricing by the stroke. J Exp Biol 207:973-982

*Wilson RP, Puetz K, Bost CA, Culik BM, Bannasch R, Reins T, Adelung D (1993) Diel dive depth in penguins in relation to diel vertical migration of prey: Whose dinner by candlelight? Mar Ecol Prog Ser 94:101-104

* Wilson RP, Ropert-Coudert Y, Kato A (2002) Rush and grab strategies in foraging marine endotherms: the case for haste in penguins. Anim Behav 63:85-95

Zimmer I, Wilson RP, Beaulieu M, Ancel A, Ploetz J (2008) Seeing the light: depth and time restrictions in the foraging capacity of emperor penguins at Pointe Géologie, Antarctica. Aquat Biol 3:217-226

Submitted: March 2, 2016; Accepted: October 11, 2016 Proofs received from author(s): November 16, 2016 